\title{
An unusual form of Ichthyophonus hoferi (Ichthyophonales: Ichthyophonaceae) from yellowtail flounder Limanda ferruginea from the Nova Scotia shelf
}

\author{
Thomas G. Rand \\ Biology Department, Saint Mary's University, Halifax, Nova Scotia, Canada B3H 3C3
}

\begin{abstract}
An unusual form of Ichthyophonus hoferi is described from 12 of 254 (4.7\%) yellowtail flounder Limanda ferruginea Storer sampled from Brown's Bank on the Nova Scotia shelf This pathogen was the cause of focal, circular to lobate, creamy-white lesions on the liver and kidneys of infected fishes. By virtue of its morphological and dimensional characteristics in the fish tissues, the histochemical profile of its thallus walls, and its development in vitro, this form was easily distinguished from 1. hoferi sensu Plehn \& Mulsow, 1911 from yellowtail flounder from other locations on the Nova Scotia shelf, and from other freshwater and marine fish species. However, gross signs of the infection, as well as the morphological, dimensional, and/or histochemical features of this form of $I$. hoferi were so remarkably similar to those of an 'I. hoferi' pathogen from L. ferruginea, Myxocephalus octodecemspinosus, and Scomber scombrus described in the literature, and to an Ichthyophonus-type pathogen from Scopelogadus beanii, as to suggest that they are the same.
\end{abstract}

KEY WORDS: Ichthyophonus hofer - Yellowtail flounder - Northwest Atlantic $\cdot$ Limanda ferruginea

\section{INTRODUCTION}

Ichthyophonus hoferi Plehn \& Mulsow, 1911 has been reported from a wide variety of host species including crustaceans (see Reichenbach-Klinke 1957 , Sindermann 1970), fishes (see Reichenbach-Klincke 1973, Wolke 1975, Neish \& Hughes 1980, Lauckner 1984), amphibians (Chauvier 1979, Herman 1984), reptiles (Chauvier 1979), and birds (Chauvier \& MortierGabet 1984). Examination of the many studies on the morphology, life history, and developmental patterns of $I$. hoferi, or what is considered to be this pathogen from both freshwater and marine fish tissues reveals that the above-mentioned features of what is supposed to be the same species are highly variable.

Reichenbach-Klinke (1973), Sindermann (1956) and McVicar (1982) have suggested that the reported variations in morphology, life history, and developmental patterns are reflections of interspecific host- effects and that the reported forms are a single species, namely Ichthyophonus hoferi sensu Plehn \& Mulsow, 1911. However, Alderman $(1976,1982)$, Johnson \& Sparrow (1961), MacKenzie (1979), and Neish \& Hughes (1980) have suggested that the genus Ichthyophonus and especially I. hoferi has become a convenient taxonomic wastebasket for poorly studied organisms often with only superficial resemblances to each other.

During a study on the biology of Ichthyophonus hoferi from yellowtail flounder Limanda ferruginea Storer from the Nova Scotia shelf (Rand 1990), it became apparent that the liver and kidneys of some of the fishes recovered from Brown's Bank were infected with a type of Ichthyphonus that was sufficiently dissimilar from I. hoferi sensu Plehn \& Mulsow, 1911 as to suggest that it was a different form. The present study describes this unusual form using light microscopy (LM), histochemistry, and cultural studies. 


\section{MATERIALS AND METHODS}

Sampling. Yellowtail flounder Limanda ferruginea were collected in March 1987 during a groundfish survey of the Brown's Bank $\left(42^{\circ} 50^{\prime} \mathrm{N}, 65^{\circ}\right.$ $40^{\prime} \mathrm{W}$ ) on the Canadian Fisheries research trawler Alfred Needler. All fish landed during the cruise were captured in a Western IIA bottom trawl with a $2 \mathrm{~cm} \mathrm{cod}$ end liner towed for $30 \mathrm{~min}$ at each fishing station.

The body and pericardial cavity of each fish was opened and the fresh viscera inspected macroscopically for lesions considered characteristic of ichthyophoniasis in yellowtail flounder (see Powles et al. 1968), as soon after capture as possible (usually willuin $8 \mathrm{hj}$.

Microscopy. Infected-tissue samples from diseased yellowtail flounder were excised using heat-sterilized scissors, placed in sterile Petri dishes, and taken to the laboratory for further study. Wet mounts of smears and tissue squashes made from infected tissues were examined microscopically. Small $\left(0.5 \mathrm{~cm}^{3}\right)$, infected tissue samples were also fixed in $10 \%$ formalseawater $(\mathrm{pH} 7.4)$ immediately after their removal from infected fish. These were then rinsed in tapwater, dehydrated, cleared, embedded in Paraplast Plus ${ }^{\circledR}$, and sectioned 4 to $15 \mu \mathrm{m}$ thick. Tissue sections were then stained using techniques described by Culling et al. (1985), Humason (1972) or Roberts (1989) as follows: Mayers' Haemalum and aqueous eosin; aqueous periodic-acid-Schiff (PAS); Alcian blue $\mathrm{pH} 1$ \& pH 2.5; Alcian blue 8-GX according to the critical electrolyte concentration procedure; Best's carmine for glycogen; van Duijin's Acrolein-Schiff reaction for proteins; Ninhydrin-Schiff reaction of alphaamino-acids; Sakuguchi's reaction for arginine; Sudan IV for bound lipids; and acid haematin for phospholipids

Samples of the pathogen from fresh, unfixed tissues were studied to determine whether the cell walls contained cellulose, chitin, or both. This was achieved using the $\mathrm{I}_{2} \mathrm{KI}$ and chitin deacetylation procedures outlined by Aronson \& Bertke (1987), and $0.1 \%$ calcofluor white (Sigma Chemical Co.) in deionized water. Calcofluor white is a nonspecific fluorochrome that binds to both cellulose and chitin in fungal cell walls (Dr M. McGinnis, Dept Pathol., Univ. of Texas Medical Branch, Galveston, TX, USA, pers. comm.). Uptake of the fluorochrome in pathogen walls was assessed by viewing them with an epifluorescence microscope equipped with a violet block filter $(380$ to $425 \mu \mathrm{m}$ excitation).

Measurements were obtained using an ocular micrometer and are in micrometers.

Mycology. For cultural morphology studies, a heat- sterilized inoculating loop was inserted inside tissue lesions that had been surface-sterilized by 2 applications of $70 \%$ ethanol. The inoculum was placed on Petri dishes containing Earl's fish saline medium (EFSM) (Rand \& Cone 1990). The inoculum was then either left uncovered, or covered with a layer of filter-sterilized seawater (32\%), incubated at $12^{\circ} \mathrm{C}$, and observed at least twice weekly for up to $4 \mathrm{mo}$. Developmental stages of the fungus were periodically removed from the Petri dishes and studied in wet-mount preparations using phase-contrast illumination.

Comparative studies. The present form of Ichthyophonus hoferi was identified by comparing morphological and dimensional features of its thâlius in yellowitail flounder tissues and its other in vitro developmental stages with the original and other descriptions of Ichthyophonus (Ichthyosporidium) gasterophilum and $I$. hoferi available in the literature (Caullery \& Mesnil 1905, Plehn \& Mulsow 1911, Axleieff 1914, Neresheimer \& Clodi 1914, Daniel 1933a, b, Fish 1934, Sproston 1944, Sindermann \& Scattergood 1954, Dorier \& Degrange 1961, Reichenbach-Klinke \& Elkan 1965, Hendricks 1972, Miyazaki \& Kubota 1977, Chein et al. 1979a, b, McVicar 1982, Herman 1984, Okamoto et al. 1985). They were also compared with $10 \%$ formalin-fixed, representative material identified as $I$. hoferi sensu Plehn \& Mulsow, 1911 from the following naturally-infected host species: Clupea harengus, provided by Dr C. Sindermann (National Marine Fisheries Service, Woods Hole, MA, USA); Pleuronectes platessa provided by Dr D. Alderman (Fish Diseases Laboratory, Weymouth, UK); Melanogrammus aeglefinus and Micromesistius poutassou from the collection of Dr R. J. Roberts (Stirling University, UK); L. ferruginea from my own collection (Rand 1990); and with the Ichthyophonus-type pathogen from Scopelogadus beanii provided by Dr J. V. Gartner Jr (University of South Florida, St. Petersburg, FL, USA).

Material for comparative morphological, and morphometric studies was dehydrated through an ethanol series, cleared briefly in xylene, and mounted in Canada Balsam. Differences in dimensions between the form described herein and material considered to be Ichthyophonus hoferi sensu Plehn \& Mulsow, 1911 were tested using a single-factor analysis of variance (ANOVA) test. The critical value, $F$, was tested at the $95 \%$ confidence level.

The holotype and representative slides of this new form of Ichthyophonus hoferi have been deposited in the National Fungal Collection, William Saunders Building, Agriculture Canada, Ottawa, Canada as follows: holotype no. DAOM 216137; representative slide no. DAOM 216138 


\section{RESULTS}

\section{Sampling}

A total of 12 of $254(4.7 \%)$ yellowtail flounder Limanda ferruginea were infected by this unusual form of Ichthyphonus hoferi. The infected fish were from the south-western region of Brown's Bank. Clinical signs were single or up to 3 focal lesions on the surface of the liver and/or kidneys of the infected fish (Fig. 1). Lesions varied from circular to lobate (Fig. 2) creamy-white patches, 0.9 to $2.3 \mathrm{~cm}$ wide. These were slightly raised above the surrounding tissue matrix, and were hard to the touch. There was no evidence of bleeding but petechiae were associated with the largest lesions in 5 of the fish. There were no external signs that any of the fish were infected.

\section{Light microscopy}

In all tissue squash and smear preparations, the only recognized developmental stage of the pathogen was a coralloid thallus (Fig. 3), 1.7 to $9 \mathrm{~mm}$ in diameter. The thallus was composed of many short, nonseptate hyaline, cylindrical to dichotomous branches 50.1 to 242.6 $\mu \mathrm{m}$ wide by $420.2 \mu \mathrm{m}$ to $5.3 \mathrm{~mm}$ long. Examination of sections of infected tissues revealed that the branches were bound by multilaminated walls (Fig. 4) 14.4 to $96.0 \mu \mathrm{m}$ thick composed of an uni-laminate inner zone surrounded by a multilaminated layer having a rough to irregular outer surface. Some of the branches had concentric restrictions along their length that gave them a jointed appearance. Branch apices were swollen and contained either unbranched or dichotomously branched cytoplasmic aggregations 259.2 to $672.0 \mu \mathrm{m}$ long by 134.4 to $470.4 \mu \mathrm{m}$ wide. Branches had a central, tubular lumen 15.4 to $42.4 \mu \mathrm{m}$ wide that usually contained spheroidal to prolate, terminal and intercalary cytoplasmic aggregates 38.5 to $77.0 \mu \mathrm{m}$ long by 19.3 to $61.6 \mu \mathrm{m}$ wide. The cytoplasm was finely reticulated, and contained vacuoles 0.96 to $3.2 \mu \mathrm{m}$ wide, spheroidal lipid-like bodies 0.96 to $3.6 \mu \mathrm{m}$ wide. Nuclei had a central or acentric, condensed nucleolus bound by a narrow translucent region that gave them a bullseye appearance (Fig. 5).

Comparison of the present form of Ichthyophonus hoferi with the specimens of $I$. hoferi sensu Plehn \& Mulsow, 1911 in naturally infected marine fish tissues and with its descriptions in the literature revealed differences in morphology and dimensions of tissue stages (Table 1). Most noticeable was the fact that $I$. hoferi sensu Plehn \& Mulsow, 1911 predominantly occurred as resting spores in relatively small, focal to confluent granulomata, and never as a coralloid thallus. Additionally, dimensions of the resting spores and

Table 1 Ichthyophonus hoferi. Comparative measurements ( $\mu \mathrm{m}$ except diameter in $\mathrm{mm}$ ) and developmental features of the unusual form of $I$. hoferi and $I$. hoferi sensu Plehn \& Mulsow, 1911 from yellowtail flounder Limanda ferruginea and the Ichthyophonus-type fungus from Scopelogadus beanii (means with ranges in parentheses). Pathogens studied were from $10 \%$ formalin-fixed fish tissues. ns: not seen

\begin{tabular}{|c|c|c|c|}
\hline \multirow[t]{2}{*}{ Feature } & \multicolumn{3}{|c|}{ Pathogen } \\
\hline & $\begin{array}{l}\text { Unusual } I \text {. hoferi } \\
\text { form }\end{array}$ & $\begin{array}{c}\text { I. hoferi sensu } \\
\text { Plehn \& Mulsow, } 1911\end{array}$ & Ichthyophonus-type \\
\hline Resting spore diameter & $\mathrm{ns}$ & $106(11.7-250.3$ & ns \\
\hline Resting spore-wall thickness & ns & $5.4(0.9-14.4)$ & ns \\
\hline Wall profile & $\begin{array}{l}\text { Rough, irregular } \\
\text { Multilaminate }\end{array}$ & $\begin{array}{l}\text { Smooth } \\
\text { Uni- to multilaminate }\end{array}$ & $\begin{array}{l}\text { Rough, irregular } \\
\text { Multilaminate }\end{array}$ \\
\hline Thallus morphology & Coralloid & ns & Coralloid \\
\hline Diameter (mm) & $5.6(1.7-9)$ & ns & $4.2(1.3-6.4)$ \\
\hline Thallus-branch thickness & $136.3(50.1-242.6)$ & ns & $109.4(42.4-207.9)$ \\
\hline Thallus branch-wall thickness & $74.3(14.4-96.0)$ & ns & $64.9(14.4-112.8)$ \\
\hline Humen width & $37.4(15.4-42.4)$ & ns & $37.4(19.3-38.5)$ \\
\hline Cytoplasm & $\begin{array}{l}\text { Reticulate to } \\
\text { finely granulated }\end{array}$ & Finely granular & $\begin{array}{c}\text { Reticulate to } \\
\text { finely granulated }\end{array}$ \\
\hline Lipid-like body diameter & $2.3(0.96-3.6)$ & $2.3(0.9-4.8)$ & $2.1(1.0-4.8)$ \\
\hline Vacuole diameter & $2.3(0.9-3.2)$ & $2.1(0.9-3.8)$ & $2.2(0.9-3.2)$ \\
\hline Nucleus diameter & $2.4(1.8-3.6)$ & $2.6(1.9-3.8)$ & $2.4(1.9-3.8)$ \\
\hline Nucleus morphology & 'Bulls eye' & 'Bulls eye' & 'Bulls eye' \\
\hline Nucleolus diameter & $1.2(0.9-1.3)$ & $1.2(0.9-1.3)$ & $1.3(0.9-1.8)$ \\
\hline
\end{tabular}



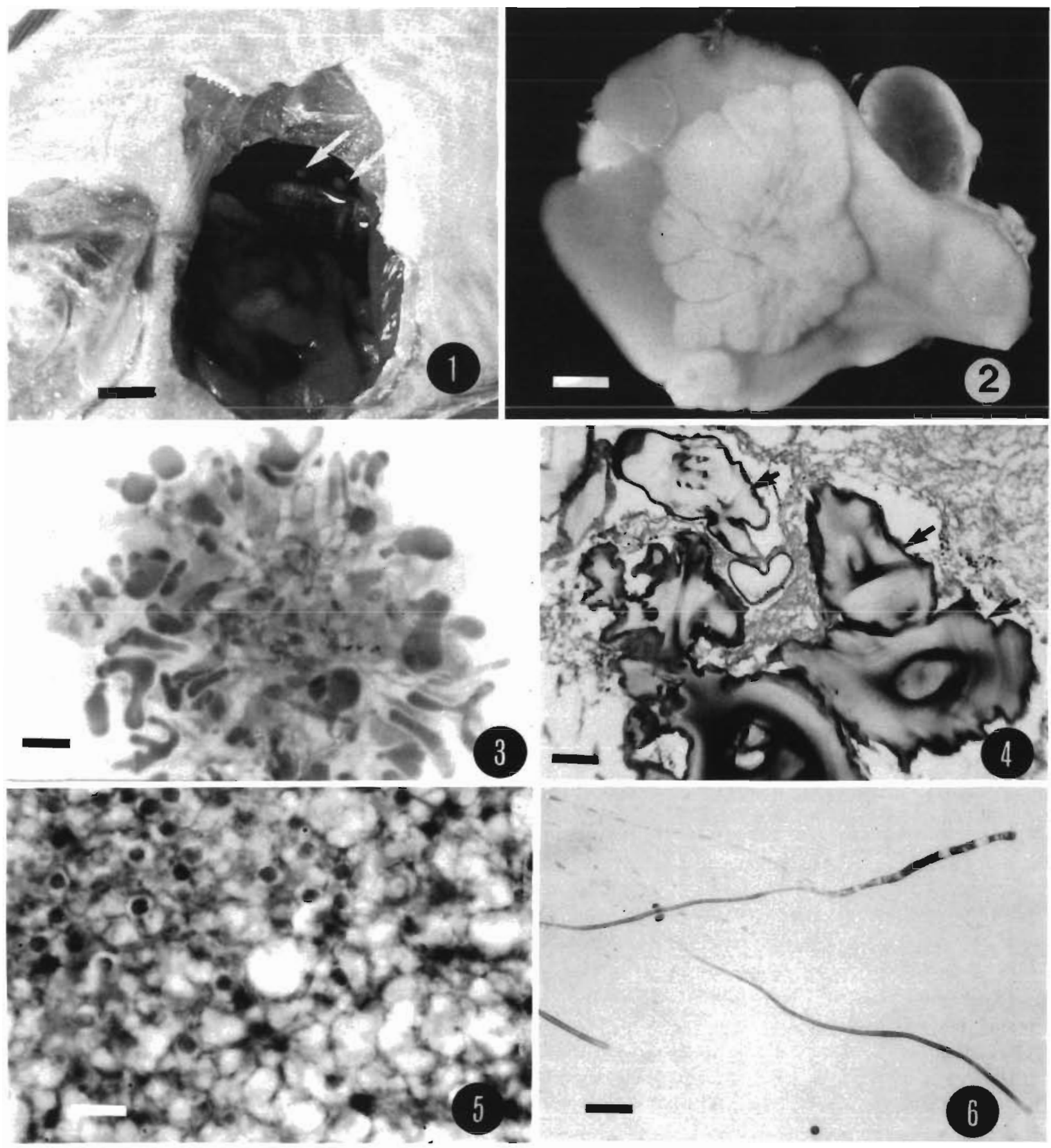

Figs. 1 to 6. An unusual form of Ichthyophonus hoferi infecting Limanda ferruginea. Fig. 1. Opened cavity of $L$. ferruginea revealing kidney infected with the unusual $I$. hoferi form (arrows). Scale bar $=2 \mathrm{~cm}$. Fig. 2 . Liver of $L$. ferruginea with a massive lesion caused by the unusual form of $I$. hoferi. Scale bar $=4.6 \mathrm{~cm}$. Fig. 3 . Whole-mount preparation of the coralloid thallus of the unusual form of $I$. hoferi from an infected yellowtail flounder. Scale bar $=1 \mathrm{~mm}$. Fig. 4. Haematoxylin-and-eosin-stained liver tissue section revealing the thick, multilaminated thallus walls (arrows) of the unusual form of $I$. hoferi. Scale bar $=50 \mu m$. Fig. 5. Haematoxylin-and-eosin-stained section of the unusual form of 1 . hoferi. Note the nuclei with their characteristic bulls-eye appearance. Scale bar $=8 \mu \mathrm{m}$. Fig. 6 . Developing sporangiophores of unusual form of $I$, hoferi on the surface of ESFM. Scale bar $=70 \mu \mathrm{m}$ 
Table 2. Ichthyophonus hoferi. Comparison of histochemical and physical profiles of resting spore walls of $I$. hoferi sensu Plehn \& Mulsow, 1911 and thallus walls of $I$. hoferi, from yellowtail flounder, and the Ichthyophonus-type pathogen, from Scopelogadus beanii. ++++: very intense reaction; +++: intense reaction; ++: moderate reaction; +: weak reaction; $(+)(-)$ : variable reaction; -: no reaction

\begin{tabular}{|c|c|c|c|c|c|c|}
\hline \multirow[t]{3}{*}{ Feature } & \multicolumn{6}{|c|}{ Pathogen } \\
\hline & \multicolumn{2}{|c|}{$\begin{array}{c}\text { I. hoferi } \\
\text { sensu Plehn \& Mulsow, } 1911\end{array}$} & \multicolumn{2}{|c|}{ I. hoferi } & \multicolumn{2}{|c|}{ Ichthyophonus-type } \\
\hline & Outer wall & Inner wall & Outer wall & Inner wall & Outer wall & Inner wall \\
\hline \multicolumn{7}{|l|}{ Carbohydrates } \\
\hline $\begin{array}{l}\text { Periodic-acid Schiff } \\
(1,2 \text { linked glycols })\end{array}$ & ++++ & ++ & ++++ & ++ & ++++ & ++ \\
\hline Control: amylase & 1 & + & ++ & ++ & + & ++ \\
\hline $\begin{array}{l}\text { Calcofluor white } \\
(1,4 \text { linked glycols })\end{array}$ & + & + & ++ & + & ++ & ++ \\
\hline Alcian blue $\mathrm{pH} 1.0$ & +++ & ++ & ++++ & ++ & ++++ & ++ \\
\hline Alcian blue pH 2.5 & ++++ & ++ & ++++ & ++ & ++++ & ++ \\
\hline \multicolumn{7}{|l|}{ Alcian blue CEC } \\
\hline $0.1 \mathrm{M} \mathrm{MgC1}_{2}$ & ++ & +++ & ++++ & ++ & ++++ & ++ \\
\hline $0.2 \mathrm{M} \mathrm{MgCl}_{2}$ & + & ++ & +++ & ++ & +++ & ++ \\
\hline $0.5 \mathrm{M} \mathrm{MgC1}_{2}$ & - & $(+)(-)$ & +++ & ++ & +++ & ++ \\
\hline $0.6 \mathrm{M} \mathrm{MgC1}_{2}$ & - & $(+)(-)$ & +++ & ++ & +++ & ++ \\
\hline $0.8 \mathrm{M} \mathrm{MgCl}_{2}$ & - & $(+)(-)$ & + & $(+)(-)$ & + & $(+)(-)$ \\
\hline $1.0 \mathrm{M} \mathrm{MgCl}_{2}$ & - & - & $(+)(-)$ & - & + & - \\
\hline Alcian blue - PAS & ++++ & + & +++ & $(+)(-)$ & $++t+$ & - \\
\hline Best's Carmine & - & - & - & - & - & - \\
\hline $\begin{array}{l}\text { Chitin deacetylation- } \\
\text { reaction }\end{array}$ & - & - & - & - & - & - \\
\hline Cellulose $\mathrm{I}_{2} \mathrm{KI}$ reaction & - & - & $(+)(-)$ & - & - & - \\
\hline \multicolumn{7}{|l|}{ Proteins } \\
\hline Aceolein-Schiff & - & - & - & - & - & - \\
\hline Millon reaction & $(+)(-)$ & - & - & - & - & - \\
\hline Ninhydrin-Schiff & ++ & + & - & - & - & - \\
\hline \multicolumn{7}{|l|}{ Lipids } \\
\hline Sudan IV & - & - & - & - & - & - \\
\hline Control: acetone & - & - & - & - & - & - \\
\hline Acid haematein & - & - & - & - & - & - \\
\hline Control: pyridine & - & - & - & - & - & - \\
\hline Polarizing microscopy & Amorphous & Isotropic & Amorphous & Isotropic & Amorphous & Isotrophic \\
\hline
\end{tabular}

resting spore walls of $I$. hoferi sensu Plehn \& Mulsow, 1911 were significantly smaller than those of the unusual form of $I$. hoferi $(\mathrm{p}<0.005)$.

\section{Histochemistry}

Comparative histochemical studies on the restingspore walls of Ichthyophonus hoferi sensu Plehn \& Mulsow, 1911 and thallus walls of the present form of the pathogen revealed that they were similar (Table 2). They exhibited differential staining properties between the inner and outer regions, contained predominately hexose sugars (vic 1, 2 glycol linking), and sulphated and acid mucosubstances. Additionally, they contained small amounts of or no stainable proteins and lipids, and no detectable cellulose nor chitin. However, the walls of these 2 forms could be distin- guished using the Alcian blue CEC procedure, and the Ninhydrin-Schiff reaction for alpha amino acids. The histochemical profile of the thallus walls of the unusual form of $I$. hoferi and of the Ichthyophonus-type pathogen were virtually indistinguishable (Table 2).

\section{Growth characteristics}

In culture, the unusual form of Ichthyophonus hoferi did not germinate or undergo any growth on LFSM without a sterile seawater overlay (Table 3 ). However, when covered by seawater, cytoplasmic aggregations at thallus apices underwent relatively rapid germination (within $12 \mathrm{~h}$ ), producing 1 to 8 sporangiophores 123.4 to $324.6 \mu \mathrm{m}$ long by 6.4 to $28.8 \mu \mathrm{m}$ wide (Fig. 6) on the surface of the medium. Initially, sporangiophores were straight to coiled structures with smooth, 
Table 3. Ichthyophonus hoferi. Comparison of some developmental features in culture of $I$. hoferi and $I$. hoferi sensu Plehn \& Mulsow, 1911 from yellowtail flounder Limanda ferruginea

\begin{tabular}{|c|c|c|}
\hline \multirow[t]{2}{*}{ Feature } & \multicolumn{2}{|c|}{ Pathogen } \\
\hline & $\begin{array}{l}\text { Unusual } \\
\text { 1. hoferi form }\end{array}$ & $\begin{array}{c}\text { I. hoferi sensu } \\
\text { Plehn \& Mulsow, } 1911\end{array}$ \\
\hline \multicolumn{3}{|l|}{ Germination } \\
\hline Without seawater overlay & No & Yes \\
\hline With seawater overlay & Within $12 \mathrm{~h}$ & Within $12 \mathrm{~h}$ \\
\hline Thallus morphology & $\begin{array}{l}\text { Nonseptate, hyaline } \\
\text { straight to coiled }\end{array}$ & $\begin{array}{c}\text { Nonseptate, hyaline } \\
\text { straight }\end{array}$ \\
\hline Mycelium & Sparse & Sparse \\
\hline Penetration of culture medium & $N_{0}$ & Yes \\
\hline Sporangia & $\begin{array}{l}\text { Elongate to globose } \\
\text { thin to thick-walled }\end{array}$ & $\begin{array}{l}\text { Elongate to globose } \\
\text { thin to thick-walled }\end{array}$ \\
\hline Spore production & $\begin{array}{l}\text { Endogenous division only } \\
\text { after } 4 \text { mo incubation }\end{array}$ & $\begin{array}{c}\text { Endogenous/exogenous division } \\
\text { within } 3 \text { wk incubation }\end{array}$ \\
\hline
\end{tabular}

thin (0.96 to $1.4 \mu \mathrm{m}$ wide) walls that surrounded cytoplasm within a central lumen. After 1 wk in culture, the cytoplasm migrated to the distal tips of the sporangiophores to form either a cylindrical to dichotomousiy branched (Fig. 7), inoperculate, thin-walled sporangium 57.8 to $134.8 \mu \mathrm{m}$ long by 34.7 to $69.3 \mu \mathrm{m}$ wide, or, a terminal, spheroidal and thick-walled $(0.96$ to $6.7 \mu \mathrm{m}$ wide) sporangium 357.8 to $98.3 \mu \mathrm{m}$ wide. After 4 mo in culture, some of the thin-walled sporangia contained spheroidal aplanospores (Fig. 8), 7.7 to $14.4 \mu \mathrm{m}$ wide with walls 0.96 to $1.8 \mu \mathrm{m}$ thick. High numbers of these spores were often found on the medium surrounding dehiscent sporangia. None of the spores exhibited amoeboid movement.

Developmental characteristics of the unusual Ichthyophonus hoferi form could be distinguished from those of $I$. hoferi sensu Plehn \& Mulsow, 1911 on
EFSM, under identical growth conditions. The former produced poorer growth, significantly smaller sporangia, and failed to produce sporangiospores within 4 mo (Tabie 3)

\section{DISCUSSION}

The morphological features of the present Ichthyophonus hoferi form from yellowtail flounder tissues are similar to but distinct from those of $I$. hoferi sensu Plehn \& Mulsow, 1911 and I. gastrophilum sensu Caullery \& Mesnil (1905) and Alexeieff (1914). All 3 groups of organisms are characterized in host tissues by having a vegetative stage with a multilaminated wall surrounding a coenocytic, highly-reticulated cytoplasm and by having nuclei with a bulls-eye appearance. Additionally, there are similarities between the
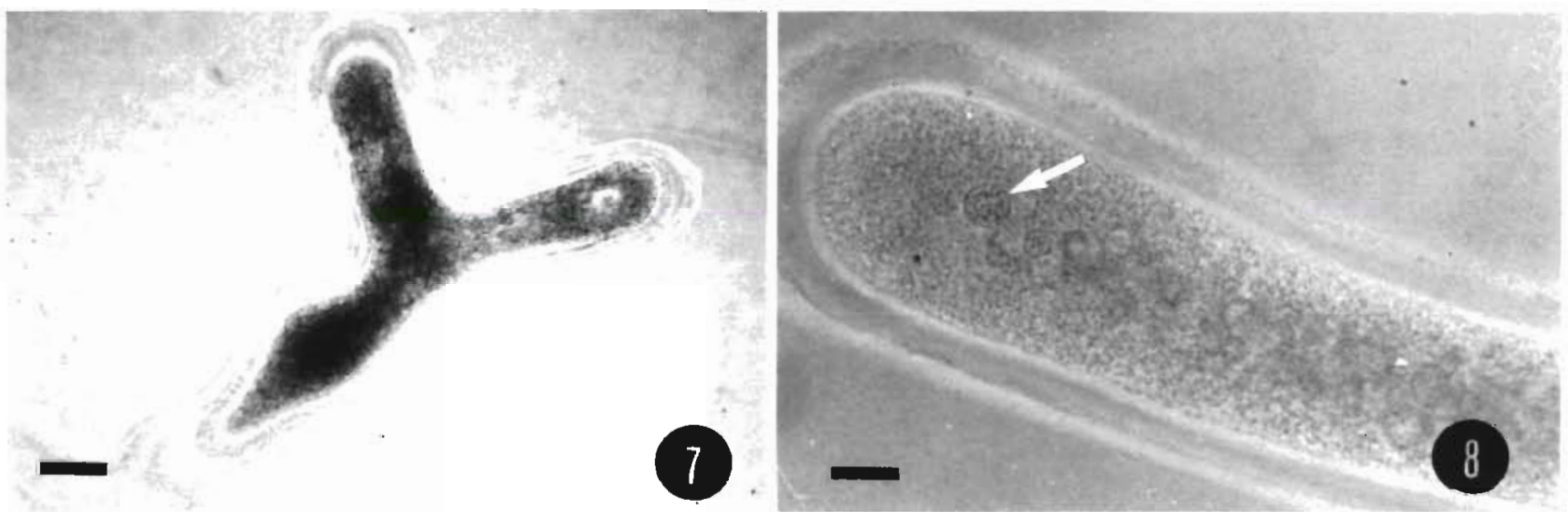

Figs. 7 \& 8. An unusual form of Ichthyophonus hoferi. Fig. 7. Dichotomously branched, immature sporangium of the unusual form of 1 . hoferi grown on ESFM. Scale bar $=20 \mu \mathrm{m}$. Fig. 8 . Sporangium of unusual form of $I$. hoferi containing thin-walled, endogenously formed spores (arrow). Scale bar $=15 \mu \mathrm{m}$ 
developmental patterns in vitro of the unusual form of I. hoferi and I. hoferi sensu Plehn \& Mulsow, 1911 from yellowtail flounder. These include the production of hyaline, nonseptate sporangiophores with cylindrical to spheroidal apical sporangia, the endogenous formation of aplanospores, and the histochemical cell-wall profiles. These similarities between these 2 pathogen forms from yellowtail flounder suggest that they are closely related.

However, the unusual pathogen type could be readily distinguished from both Ichthyophonus hoferi sensu Plehn \& Muslow, 1911 and I. gasterophilum by virtue of its coralloid thallus composed of short, stout, swollen branches that contained cytoplasmic aggregations at their tips. This type of vegetative structure apparently has never been reported for $I$. hoferi sensu Plehn \& Muslow, 1911 or for I. gasterophilum Caullery \& Mesnil, 1905. The present organism could also be distinguished from $I$. hoferi sensu Plehn \& Mulsow because it failed to grow in culture without a sterile-seawater overlay, and because even when covered by sea water it exhibited poor growth and produced significantly smaller sporangia than $I$. hoferi sensu Plehn \& Mulsow from yellowtail flounder grown under identical conditions. These observations suggest that these 2 forms of this pathogen differ with respect to their growth requirements. Additionally, the unusual form of $I$. hoferi could be distinguished from $I$. hoferi sensu Plehn \& Mulsow on the basis that its walls reacted more intensely with Alcian blue stains than those of the latter. These data not only suggest that the walls of the vegetative structures of these 2 pathogens in fish tissues differ somewhat in their chemical composition, but that histochemistry may provide a useful tool for the differentiation of strains within the species $I$. hoferi, and pathogens that have been variously assigned to this genus (see Rand 1990).

While it is tempting to establish this unusual form of Ichthyophonus hoferi as a new species of Ichthyophonus, it must be recognised that the taxonomy of this group is presently in a state of considerable confusion, especially because there is no clear definition of I. hoferi sensu Plehn \& Mulsow, 1911. It would seem premature, therefore, to begin subdividing the genus at this time. In my view, it is essential that detailed analytical taxonomic approaches involving life-cycle and ultrastructural studies, and direct-sequence-analysis of DNA and RNA molecules from these various pathogens considered to be $I$. hoferi be undertaken before a new species is claimed.

The unusual form of Ichthyophonus hoferi reported herein is similar in appearance to the pathogen identified as ' $I$. hoferi' by Hendricks (1972) from the kidneys of Limanda ferruginea and Myxocephalus octodecemspinosus and to the Ichthyophonus-type pathogen from Scopelogadus beanii reported on by Gartner \& Zwerner (1988). Examination of their figures showed the pathogen(s) to have a thick, irregular wall associated with a large solitary lesion that was identical to the lesions in yellowtail flounder kidneys reported on here. This striking similarity in pathogen morphology in kidney tissues and in pathology suggests that all of these pathogens are likely the same entity: the unusual form of $I$. hoferi. This would support suggestions of Alderman (1976, 1982), Johnson \& Sparrow (1961), Mackenzie (1979), and Neish \& Hughes (1980) that the genus Ichthyophonus and especially I. hoferi sensu Plehn \& Mulsow, 1911 has been used as a wastebasket for improperly studied pathogens that have only superficial resemblances to each other.

Morphological features of this pathogen from Limanda ferruginea are also similar in some respects to some of the vegetative stages of the Ichthyophonus hoferi from mackerel Scomber scombrus described by Sproston (1944). Sproston's (1944) I. hoferi has been the source of much confusion in the literature because there was little agreement among workers as to whether it was I. hoferi sensu Plehn \& Mulsow, 1911. Its morphology and developmental patterns in infected tissues were most unusual (Alderman 1982, McVicar 1982, Neish \& Hughes 1982, Laucker 1984). Inspection of Figs. 1, $10 \& 18 \mathrm{in}$ Sproston (1944) shows that her organism had an ovoid to coralloid thallus with short, stubby, irregularly shaped branches similar to those of the unusual $I$. hoferi form described herein, and resting spores typical of $I$. hoferi sensu Plehn \& Mulsow, 1911. Whether all of the developmental stages that Sproston (1944) encountered in mackerel represented those of a single organism is unknown. It is possible that the infected mackerel studied by Sproston (1944) were infected concurrently with both forms of $I$. hoferi.

Acknowledgements. The assistance of Drs D. Alderman, J. Gartner $J_{\mathrm{r}}, \mathrm{R}$. J. Roberts, C. Sindermann, D. Miller and $N$. Whitney is gratefully appreciated. Financial support from a NSERC postgraduate scholarship, the Department of Biology at the University of New Brunswick, and the University of New Brunswick Vaughan Marine Science Fellowship is also gratefully acknowledged.

\section{LITERATURE CITED}

Alderman, D. J. (1976). Fungal diseases in marine animals. In: Jones, E. B. G. (ed.). Recent advances in marine mycology. Paul Elek, London, p. 223-260

Alderman, D. J. (1982). Fungal diseases of aquatic animals. In: Roberts, R. J. (ed.) Microbial diseases of fish. Academic Press, London, p. 189-242

Alexeieff, A. (1914). Sur le cycle évolutif d'un haplosporidie (Ichthyosporidium gasterophilum Caullery et Mesnil). Archs Zool. exp. gén. 54: 30-44 
Aronson, J. M., Bertke, C. C. (1987). Isolation and analysis of cell walls. In: Fuller, M. S., Jaworski, A. (eds.) Zoosporic fungi in teaching and research. Southeastern Publ. Co., Athens, p. 175-185

Caullery, M., Mesnil, F. (1905). Recherches sur les haplosporidies. Archs Zool. exp. gén. (Ser. 4) 4: 101-181

Chauvier, G. (1979). Mycose viscerale de poissons duclaguicoles tropicaux. Annls Parasit. (Paris) 54:105-111

Chauvier, G., Mortier-Gabet, J. (1984). Premières observations du pouvoir pathogène d'Ichthyophonus pour des oiseaux. Annls Parasit hum. comp. 59: 427-431

Chien, C. H., Miyazaki, T., Kubota, S. (1979a). Studies on Ichthyophonus disease of fishes. V. Culture Bull. Fac. Fish. Mie Univ. 6: 161-172 (in Japanese, English summary and plate legends)

Chien, C. H., Miyazaki, T., Kubota, S. (1979b). Studies on Ichthyophonus disease of fishes. VII. Morphology and life cycle. Bull. Fac. Fish. Mie Univ. 6: 161-172 (in Japanese, English summary and plate legends)

Culling, C. F. A., Allison, R. T, Barr, W. T (1985). Cellular pathology technique. Oxford Univ. Press, Toronto

Daniel, G. E. (1933a). Studies on Ichthyophonus hoferi, a parasitic fungus of the herring, Clupea hareugus. I. The parasite as it is found in the herring. Am. J. Hyg. 17: 262-276

Daniel, G. E. (1933b). Studies on Ichthyophonus hoferi, a parasitic fungus of the herring, Clupea hareugus. II. The gross and microscopic lesions produced by the parasite. Am. J. Hyg. 17: 491-501

Dorier, A., Degrange, C. (1961). L'évolution de l'lchthyosporidium (Ichthyophonus) hoferi (Plehn et Mulsow) chez les salmonides d'élevage (truite arc en ciel at saumon de fontaine). Trav. Lab. Hydrobiol. Piscic. Univ. Grenoble 52/53: $7-44$

Fish. F. F. (1934). A fungus disease in fishes of the Gulf of Maine. Parasitology 26: 1-16

Gartner, J. V. Jr, Zwerner, D. E. (1988). An Ichthyophonustype fungus in the deep-sea pelagic fish Scopelogadus beanii (Gunther) (Pisces: Melamphaidae): pathology, geographical distribution and ecological implications. J. Fish Biol. 32: $459-470$

Hendricks, J. D. (1972). Two new host species for the parasitic fungus Ichthyophonus hoferi in the Northwest Atlantic. J. Fish. Res. Bd Can. 29: 1776-1777

Herman, R. L. (1984). Ichthyophonus-like infection in newts (Notophthalmus viridescens Rafinesque). J. Wildife Dis. 20: $55-56$

Humason, G. L. (1972). Animal tissue techniques. W. H. Freeman and Co., San Francisco

Johnson, T. W. Sparrow, F. K. (1961). Fungi in oceans and estuaries. Cramer, Weinheim

Lauckner, G. (1984). Diseases caused by microorganisms: agents: fungi. In: Kinne, $O$. (ed.) Diseases of marine animals, Vol. IV, Pt. 1. Biologische Anstalt Helgoland, Hamburg, p. 89-113

MacKenzie, K. (1979). Some parasites and diseases of blue whiting Micromesistius poutassou (Rissou), to the North and West of Scotland and at the Faroe Islands. Scot. Fish Res. Rep. 17: 1-14

McVicar, A. H. (1982). Ichthyophonus infection of fish. In:
Roberts, R. J. (ed.) Microbial diseases of fish. Academic Press, London, p. 243-269.

Miyazaki, T., Kubota, S. (1977). Studies on Ichthyophonus disease of fish. I. Rainbow trout fry. Bull. Fac. Fish. Mie Univ $4: 45-56$

Neish, G. A., Hughes, G. C. (1980). Fungal diseases of fishes, Book 6. In: Sniesko, S. F., Axelrod, H. R. (eds.) Diseases of fishes. T.F.H. Publications, Neptune City

Neresheimer, E., Clodi, C. (1914). Ichthyophonus hoferi Plehn and Mulsow, der Erreger der Taumelkrankheit bei Salmoniden. Arch. Protistenkd. 34: 217-248

Okamoto, N., Nakase, K., Suzulki, H., Nakai, Y., Fujii, K., Sano, T. (1985). Life history and morphology of Ichthyophonus hoferi in vitro. Fish Pathol. 20: 273-285

Plehn, M., Mulsow, K. (1911). Der Erreger der Taumelkrankheit der Salmoniden. Zbl. Bakt. ParasitKde. (Orig.) 59: $63-68$

Powles, P. M., Garnett, D. G., Ruggieri, G. D., Nigrelli, R. F. (1968). Jchthyophonus infection in vellowtail flounder (Limanda ferruginea) off Nova Scotia. J. Fish. Res. Bd Can. 25: $597-598$

Rand, T. G. (1990). Studies on the biology of Icthyophonus hoferi Plehn and Mulsow, 1911 from Nova Scotian yellowtail flounder, Limanda ferruginea (Storer). Ph.D. thesis, University of New Brunswick, Fredericton

Rand, T. G., Cone, D. (1990). Effects of Ichthyophonus hoferi Plehn and Mulsow 1911 on conditions indices and blood chemistry of experimentally-infected rainbow troui (Oncorhynchus mykiss). J. Wildilife Dis. 26 $323-328$

Reichenbach-Klinke, H. H. (1957). Augenschaden bei Meeresfischen durch den Pilz Ichthyosporidium hofert (Plehn and Mulsow) und Bemerkungen zu seiner Verbreitung bei Mittelmeerfischen. Publ. Staz. zool. Napoli 29: 22-32

Reichenbach-Klinke, H. H. (1973). Fish pathology. T.F.H. Publications, Neptune City

Reichenbach-Klinke, H. H., Elkan, E. (1965). The principle diseases of Jower vertebrates, Book 1 Diseases of fishes. T.F.H. Publications, Neptune City

Roberts, R. J. (ed.) (1989). Fish pathology. Balliere Tindall, London

Sindermann, C. J. (1956). Diseases of fishes of the western North Atlantic. IV. Fungus disease and resultant mortalities of herring in the Gulf of St. Lawrence in 1955. Maine Dept Sea Shore Fish. Res. Bull. 25: 1-23

Sindermann. C. J. (1970). Principal diseases of marine fish and shellfish. Academic Press, New York

Sindermann. C. J., Scattergood, L. W. (1954). Diseases of fishes of the western North Atlantic. II. Ichthyosporidium disease of the sea herring (Clupea harengus). Maine Dept Sea Shore Fish Res. Bull. 19: 1-40

Sproston, N. G. (1944). Ichthyosporidium hoferi (Plehn and Mulsow, 1911), an internal fungoid parasite of the mackerel. J. mar biol. Ass. U.K. 26: 72-98

Wolke, R. E. (1975). Pathology of bacterial and fungal diseases affecting fish. In: Ribelin, W. E, Migaki, G. (eds.) The pathology of fishes. Univ. of Wisconsin Press, Madison, p. 33-116

Manuscript first received: September 18, 1991

Revised version accepted: July 12, 1993
Responsible Subject Editor: T. Evelyn, Nanaimo, B.C., Canada 